\title{
Improving the Energy Efficiency in Lonza Ltd, Visp
}

\author{
Andrej Szijjarto*
}

\begin{abstract}
Over the past few decades, the development of the energy market was marked by market liberalization, a surging appetite for energy in the developing world, constantly high energy prices, energy security concerns, a growing awareness of climate change, and introduction of the emissions trading. These issues result in the growing importance of energy efficiency for the chemical and life science industries. This article describes a systematic approach to achieve higher energy efficiency in the Swiss chemical and life science company Lonza Ltd. A particular energy-saving project focusing on the optimization of infrastructure is presented.
\end{abstract}

Keywords: Energy efficiency · Energy management · Long-distance steam pipeline $\cdot$ Steam consumption

\section{Energy Saving in the Chemical and Life Science Industries}

In the chemical and life science industry, energy represents up to $10 \%$ of the overall costs, ${ }^{[1]}$ making it an important item in inter- and intra-enterprise competition. This percentage becomes more important if it is considered that $60 \%$ of the overall cost is fixed and refers to raw materials cost, leaving just $40 \%$ for potential cost savings. Therefore, energy efficiency, environmental protection, and chemical waste management have attracted increasing attention. Effective energy utilization and energy management in production facilities are desirable for reducing processing costs, conserving nonrenewable energy resources, and reducing environmental impact. The chemical and life science industry, on the one hand, consumes large amounts of energy and, on the other hand, generates large amounts of chemical waste. Energy conservation and energy recovery from chemical wastes have become two important issues to reduce production costs, maintain economic growth, and improve sustainability in our industry.

${ }^{*}$ Correspondence: Dr. A. Szijjarto

Project Engineer Energy \& Waste Management Lonza Ltd

Rottenstrasse 6

$\mathrm{CH}-3930$ Visp

Tel.: +41279485293

E-mail: andrej.szijjarto@lonza.com
The chemical industry is a significant target when it comes to focusing on energy efficiency improvement in the context of decreasing the environmental burden of the industrialized nations. The ambient factors influencing energy efficiency of chemical production companies are shown in Fig. 1.

With respect to specialty chemical and pharmaceutical manufacturing, the product life cycle creates an additional driving force for the optimization of the process including energy efficiency, particularly as the patent protection approaches its expiration as depicted in Fig. 2.

The life cycle of a specialty chemical starts with the innovation and process design stage. When designing a process for a specialty chemical, priority tends to be given to the product rather than to the process; therefore, the energy-saving motivation is

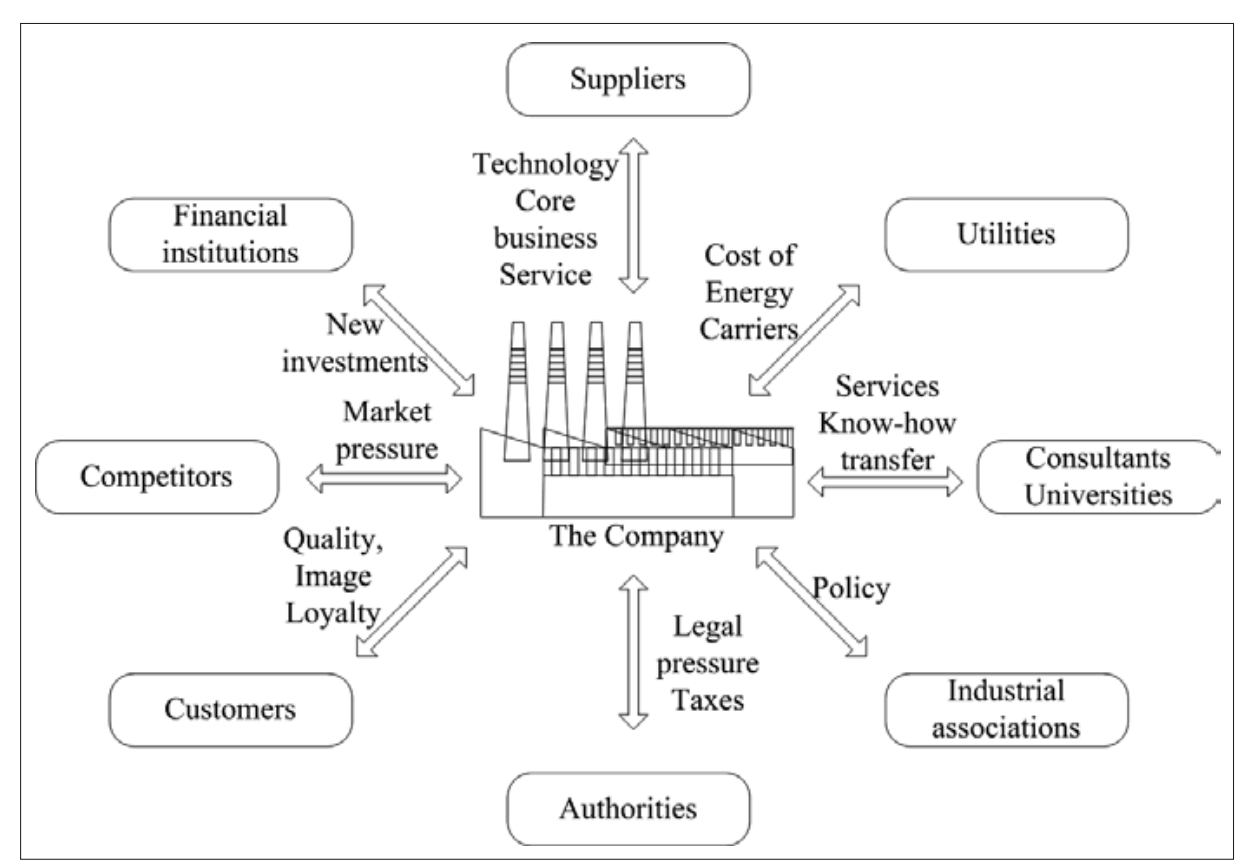

Fig. 1. Factors influencing energy efficiency in chemical production. relatively low at this stage. This is because the unique function of the product must be protected. The process is likely to be small scale and operating costs tend to be less important than with commodity chemical processes. The capital cost of the process will be low relative to commodity chemical processes because of the scale. The time to market of the product is also likely to be important with specialty chemicals, especially if there is patent protection. If this is the case, then anything that shortens the time from basic research, through to product testing, pilot plant studies, process design, construction of the plant to product manufacturing will have an important influence on the overall project profitability. ${ }^{[3]}$ After the launch of the production in the plant scale, the optimization of the process becomes an important issue. In particular, 


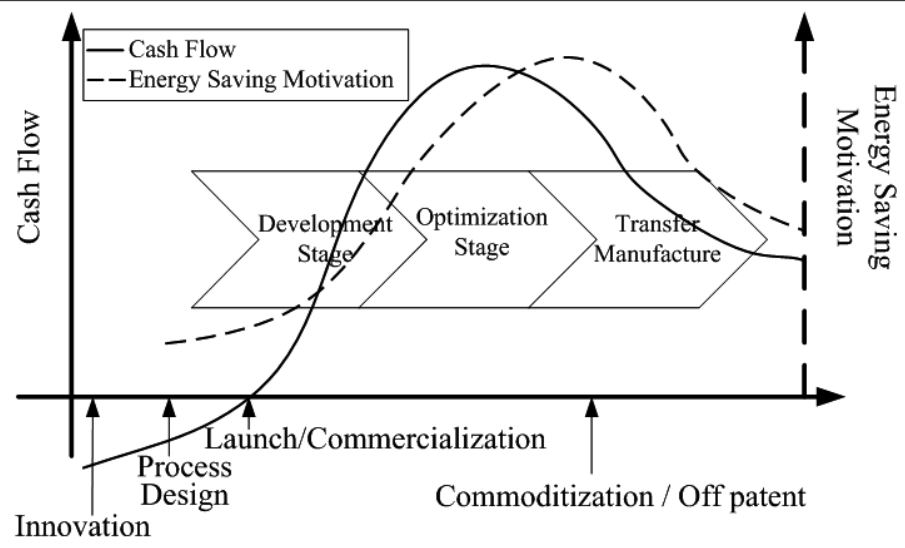

Fig. 2. Energy saving in the context of the life cycle of the specialty chemicals (implemented from ref. [2]).

some of the energy systems might be oversized, resulting in high-energy consumption and an unreliable control of the process parameters. Moreover, this can lead to fluctuations in quality, which is highly undesirable in the specialty chemicals sector. Therefore, the motivation for process optimization, including energy saving exponentially rises in this stage of the life cycle. Energy-saving motivation peaks after the specialty chemical product has passed the maturity stage, and its sales and profitability start to decline. The main reason is to keep the production profitable and competitive as long as possible by cutting the production costs. When the critical point in the profitability of the product is reached, the manufacture is transferred to the lowcost destination.

\section{Energy Optimization Workflow at Lonza Ltd}

The practical implementation of energy optimization workflow at Lonza Ltd is depicted in Fig. 3. After an initial collection of the historical data, the Key Performance Indicators (KPI) and energysaving goals are defined. As a next step, a set of energy-saving opportunities is compiled. Commonly considered energy-saving opportunities are listed in the Table 1. Then, the detailed evaluation of particular alternatives is carried out. The main goal in this step is to quantify the investment costs as well as the annual savings of different alternatives. Using this data, a static payback (SP) can be calculated as:

$$
S P=\frac{\text { Annual Cost Savings }[\mathrm{CHF} / \mathrm{a}]}{\text { Total Investment }[\mathrm{CHF}]}
$$

Based on the SP of different alternatives, together with technical uncertainties, most promising projects are selected for further realization.

Finally, the monitoring provides useful information when implementing detailed

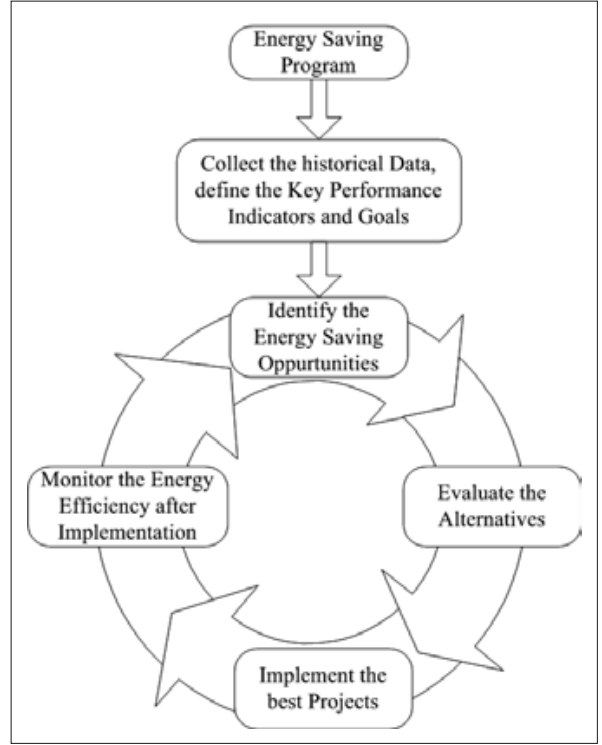

Fig. 3. Energy optimization workflow at Lonza Ltd.

Table 1.

\begin{tabular}{|c|c|c|c|}
\hline & Area & Type & Project example \\
\hline \multirow{10}{*}{ 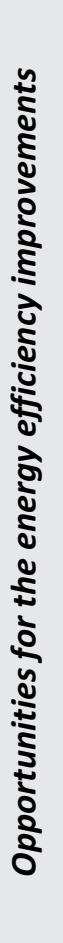 } & \multirow{4}{*}{ 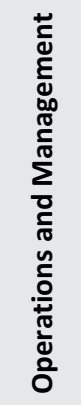 } & $\begin{array}{l}\text { Proactive } \\
\text { maintenance }\end{array}$ & $\begin{array}{l}\text { Compressed air pipeline leakage detection, steam traps } \\
\text { monitoring }\end{array}$ \\
\hline & & $\begin{array}{l}\text { Improved } \\
\text { operating } \\
\text { procedures }\end{array}$ & $\begin{array}{l}\text { Debottlenecking of the batch processes leading to a shorter } \\
\text { cycle time i.e. lower energy consumption }\end{array}$ \\
\hline & & $\begin{array}{l}\text { Capacity } \\
\text { utilization }\end{array}$ & $\begin{array}{l}\text { Production at the optimal operating point followed by } \\
\text { the shut-down (Stop \& Go production strategy) }\end{array}$ \\
\hline & & $\begin{array}{l}\text { Improved } \\
\text { waste } \\
\text { management }\end{array}$ & $\begin{array}{l}\text { Optimal usage of the waste solvents (recycling vs. } \\
\text { incineration) }\end{array}$ \\
\hline & \multirow{6}{*}{ 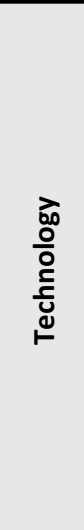 } & $\begin{array}{l}\text { Optimized } \\
\text { control } \\
\text { strategy }\end{array}$ & $\begin{array}{l}\text { Optimization of the temperature control systems } \\
\text { of the batch reactors avoiding simultaneous heating and } \\
\text { cooling }\end{array}$ \\
\hline & & $\begin{array}{l}\text { New energy } \\
\text { efficient } \\
\text { equipment }\end{array}$ & Installation of the new energy efficient motors \\
\hline & & $\begin{array}{l}\text { Equipment } \\
\text { revamp }\end{array}$ & Installation of the Variable Speed Drives (VSDs) \\
\hline & & $\begin{array}{c}\text { Process } \\
\text { optimization }\end{array}$ & $\begin{array}{l}\text { Utilization of a new catalyst leading to considerably } \\
\text { lower pressure/temperature in the reactor }\end{array}$ \\
\hline & & $\begin{array}{l}\text { Infrastructure } \\
\text { optimization }\end{array}$ & $\begin{array}{l}\text { Long distance steam pipeline from the } \\
\text { municipal waste incineration plant }\end{array}$ \\
\hline & & $\begin{array}{l}\text { Heat } \\
\text { integration }\end{array}$ & $\begin{array}{l}\text { Utilization of the process waste heat through the Heat } \\
\text { Exchanger Network (Pinch analysis) }\end{array}$ \\
\hline
\end{tabular}

energy efficiency measures. It also ensures accountability by providing feedback on performance improvement measures that have been implemented and assessing energy savings achieved.

Very low-cost operational changes are considered to save typically $10-20 \%$ on utility bills (low-hanging fruit). Capital investment programs with acceptable payback times can save an additional 20$30 \%$.[4] In most cases, the reduction of energy cost will also reduce emissions of environmental pollutants. This may further reduce the costs for the control of environmental pollution.

\section{Example Project - Long-distance Steam Pipeline}

As an example of Lonza's energysaving projects, a long-distance steam pipeline is presented. This project focused on the optimization of the infrastructure. Concretely, the waste thermal energy in form of steam from the nearby municipal waste incineration plant (KVA) was integrated into the Lonza's steam system. The steam from the KVA was, prior to this project, used to generate electricity and then condensed by the air condenser, i.e. the thermal energy was dissipated into the atmosphere. The overall efficiency of the system was $25 \%$.

In order to increase the efficiency of the system, a long-distance steam pipeline was constructed, as depicted in Fig. 4.

Additionally, the turbine at KVA had to be modified and the turbine at Lonza 


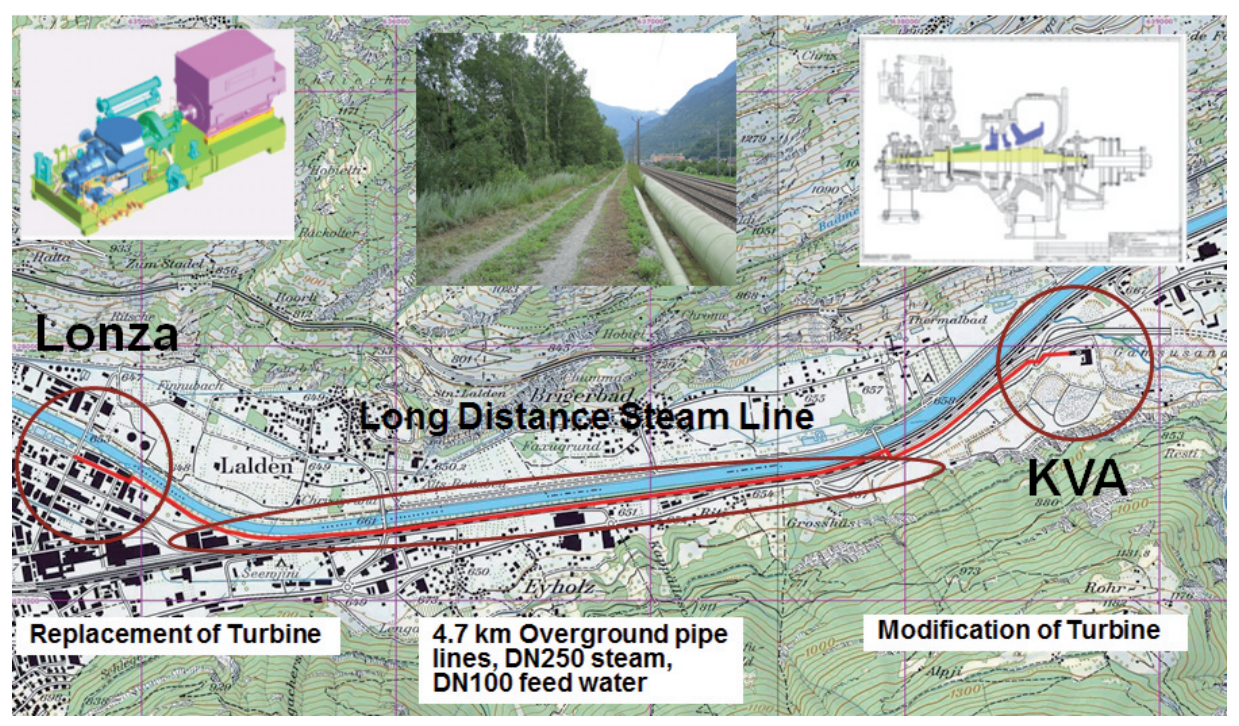

Fig. 4. Long-distance steam pipeline - geographical situation. replaced with a new one, which allowed more flexible operation.

The project was initiated in January 2009 and has been in regular operation since January 2011. The total investment cost reached CHF 22 Mio. As a main benefit of the project, 100GWh/a energy in the form of steam could be saved. Additionally, $\mathrm{CO}_{2}$ emissions were reduced by 22'000 t/a. The overall efficiency of the system was increased to $75 \%$.

Received: August 16, 2013

[1] B. Allen, M. Savard-Goguen, L. Gosselin, Appl. Therm. Eng. 2009, 29, 3437.

[2] R. Bloodworth, 'Globalization in the Fine Chemicals Industry - Opportunities in Specialty Chemicals', retrieved on 05-11-2011 from http://www.indiachem.in/Presentations/Day3/ SessiononGrowth\&OpportunitiesforSpecialtyChemicals/Dr.RobertBloodworth.pdf

[3] R. Smith, 'Chemical Process Design and Integration', 2005, John Wiley and Sons Ltd, Chichester.

[4] B. L. Capehart, W. C. Turner, W. J. Kennedy, 'Guide to Energy Management', 2008, CRC Press. 